Discussion Papers
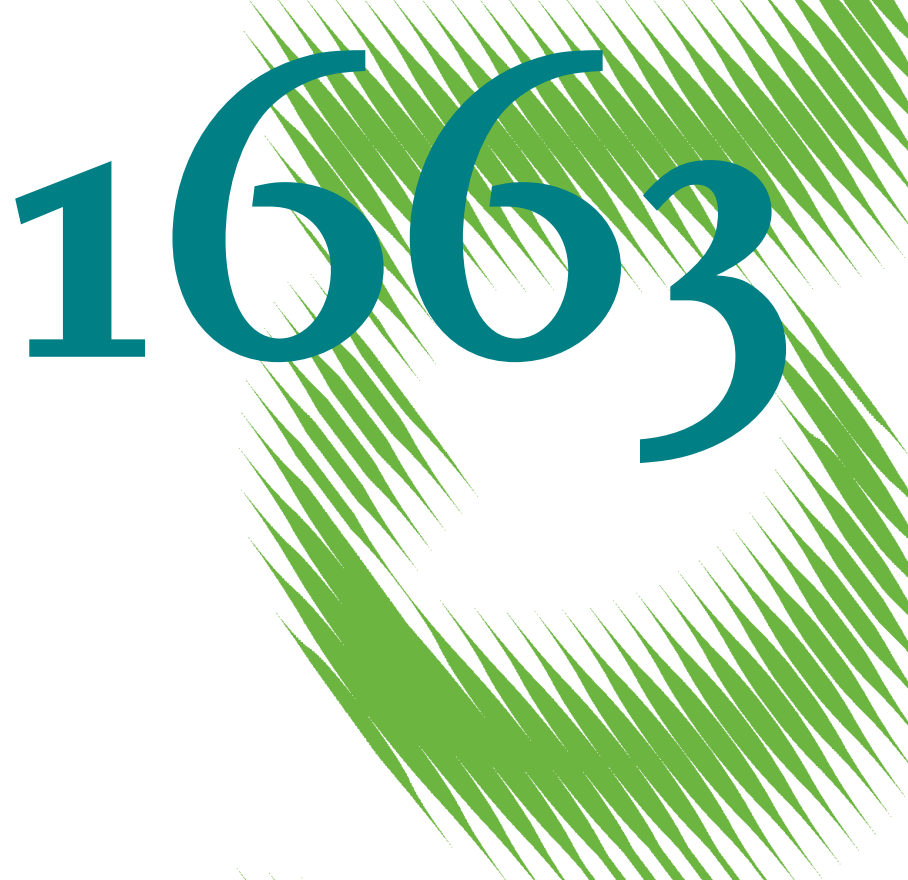

Distributed Photovoltaic Power Generation: Possibilities, Benefits, and Challenges for a Widespread Application in the Mexican Residential Sector 
Opinions expressed in this paper are those of the author(s) and do not necessarily reflect views of the institute.

IMPRESSUM

(C) DIW Berlin, 2017

DIW Berlin

German Institute for Economic Research

Mohrenstr. 58

10117 Berlin

Tel. +49 (30) $89789-0$

Fax +49 (30) $89789-200$

http://www.diw.de

ISSN electronic edition 1619-4535

Papers can be downloaded free of charge from the DIW Berlin website:

http://www.diw.de/discussionpapers

Discussion Papers of DIW Berlin are indexed in RePEc and SSRN:

http://ideas.repec.org/s/diw/diwwpp.html

http://www.ssrn.com/link/DIW-Berlin-German-Inst-Econ-Res.html 


\title{
Distributed photovoltaic power generation: possibilities, benefits, and challenges for a widespread application in the Mexican residential sector
}

\author{
Pedro I. Hancevic, Hector M. Nuñez and Juan Rosellón* \\ Centro de Investigación y Docencia Económicas
}

April 2017

\begin{abstract}
Mexico plans to implement a national program to support the adoption of distributed photo-voltaic generation (DPVG) among qualified households. The main objectives of such a program would be to reduce the burden of the substantial federal energy subsidy and increase the share of renewable energy sources used to generate electricity. In this paper we assess the current conditions under which the Mexican residential electricity sector operates, and quantify the potential effects that the massive adoption of DPV systems would have on household expenditure and welfare, subsidy reduction, pollution and water resource usage. Based on the positive results in terms of both economic and environmental effects, our paper provides a significant support for further design and implementation of a DPVG program.
\end{abstract}

JEL classifications: Q28, Q42, Q53

Keywords: distributed solar photovoltaic generation, residential electricity consumption, energy subsidies, air pollution, water resource usage.

\footnotetext{
${ }^{*}$ Corresponding author: pedro.hancevic@ cide.edu

An earlier version of this paper was presented in the Energy and Environment Seminar organized by CAF Development Bank of Latin America and the Latin American Economic Research Foundation (FIEL) held at the Buenos Aires Stock Exchange (Bolsa de Comercio de Buenos Aires). We would like to thank Diego Margulis, Fernando Navajas, Santiago Urbiztondo and seminar participants at CIDE for their helpful comments and suggestions. Excellent research assistance was provided by Hugo Salas Rodriguez and Alejandro Lopez Aguilar. All remaining errors are our own.
} 


\section{Introduction}

About $90 \%$ of Mexican energy consumption comes from fossil fuels, including most of the electricity generated in the country. Mexico is the 13th largest Greenhouse Gas (GHG) emitter in the world and the second in Latin America -only behind Brazil-, contributing with approximately $1.4 \%$ of the global GHG emissions (Damassa et al., 2015; Mexico Gobierno de la Republica, 2015). Among the current and expected consequences of climate change that directly impact on the country, we find more frequent and severe hurricanes and tornados, extended droughts that affect the quality and quantity of water resources, adverse effects on agricultural activities (which also put at risk food security), and drastic coastal flooding and erosion episodes. The country's environmental goals, in accordance with the Intended Nationally Determined Contribution affirmed at the climate summit held in Paris in 2015 (COP-21), require that $35 \%$ and $43 \%$ of domestic energy should come from renewable sources by 2024 and 2030, respectively. Meeting that goal is likely to require, among other steps, significant changes in the current electricity generation mix. The Mexican Energy Reform (December, 2013) opened an important window to introduce renewable energies in this sector, particularly solar energy. ${ }^{1}$

To be more concrete, electricity generation explains more than $20 \%$ of total GHG emissions in Mexico. The residential sector, in turn, accounts for $25 \%$ of total electricity consumed. In this context, taking advantage of the fact that more than $75 \%$ of the country has an isolation greater than $5 \mathrm{kWh} / \mathrm{m}^{2} /$ day, seems to be a very promising energy and environmental policy opportunity. Other countries, such as Germany and Spain, are currently recognized as the world leaders in installed PV systems. However, Mexico's solar potential resources are far superior and could be considered among the largest in the world (see, for example, SENER

\footnotetext{
${ }^{1}$ In December 2015, Mexico's constitution was amended to create competition in the energy sector through the introduction of private investment, including the hydrocarbon sector (upstream, midstream and downstream) and the power sector (generation, transmission and distribution). The amendments maintained the state ownership and control of subsoil resource and were intended to modernize the state energy companies. One of the main goals was to reduce direct intervention of government and replace it with rational economic regulation.
} 
(2016)).

On the other hand, the federal government through the state-owned electricity company (Comisión Federal de Electricidad, CFE) promotes excessive residential electricity demand by subsidizing more than $98 \%$ of Mexican households. The residential tariff structure consists of a multiple-block scheme and incorporates different regional marginal prices which are linked to average temperatures -i.e. high temperature zones afford lower marginal prices. ${ }^{2}$ The fiscal burden associated to the electricity consumption of the residential sector has consistently increased during the last decade and currently represents more than $0.5 \%$ of the GDP. Moreover, given the universal and uniform application of this subsidy, the tariff scheme magnifies the inclusion error, wasting valuable resources. All this happens in the context of a country where poverty and inequality are significant social problems.

As a result, an ambitious plan aiming to deploy distributed photo-voltaic systems (DPV) among qualified households -i.e. those able to adopt solar technology in their rooftops- could help solve some of the challenges that Mexico is currently facing. A household adopting a DPV system would be ideally grid-connected so it could purchase electricity when the system is not producing enough power, or sell electricity when it over produces. The potential advantages include: first, a reduction of the fiscal burden (which today represents a figure of more than 5 billion of USD per year). Second, the DPVG program could bring significant GHG emissions savings by reducing traditional fossil fuel electricity generation (helping Mexico to comply with the energy and environmental goals). ${ }^{3}$ Third, it could make possible to avoid costly future investments in traditional electricity generation, transmission and distribution since households adopting DPV systems would be grid-connected.

\footnotetext{
${ }^{2}$ Mexico has one of the most complex tariff and subsidy structures in the world, see for example Komives et al. (2009) and Lopez-Calva and Rosellón (2002).

${ }^{3}$ Using GHG emissions in 2000 as baseline, the General Law of Climate Change (passed in 2012) has two main goals: first a reduction of $30 \%$ by 2020 , and second a reduction of $50 \%$ by 2050 . In the same spirit and as part of the extensive and deep Energy Reform of December 2013, the Clean Energy Certificates (a.k.a. RECs) seek to promote greater electricity generation from clean (mainly renewable) energy sources.
} 
In this paper, we provide a comprehensive assessment of the current conditions under which the Mexican residential electricity sector operates. Using the characterization of Mexican households and simulating an scenario of massive DPV system adoption, we measure the potential subsidy savings and the benefits to residential users. ${ }^{4}$ Also, from an environmental perspective, we estimate the reduction in air pollution emissions and water resource usage associated to the simulated scenario. ${ }^{5}$ Finally, we provide some policy suggestions about how the current electricity consumption subsidy could be (partially) converted into a DPV system adoption subsidy, standing up for an integral selection mechanism aiming to target the poor in an accurate way.

\section{Literature review}

We analyze the possibilities and the impact that massive rooftop solar panel installation in the Mexican residential sector would have on a set of relevant socio-economic variables: household welfare, government budget, air pollution and water resources usage. The available related literature for Mexico and other emerging countries is relatively scarce and, most of the times, is focused on a narrower set of issues. Grande et al. (2015) analyzes the profitability of DPV systems for a narrow subset of high-consumption users in Mexico. The calculations made in that study do not use micro-data and are based on industry average figures for the year 2010. Alemán-Nava et al. (2014) presents an overview of the renewable energy options available in Mexico without focusing on any particular energy source. Our paper belongs to broader branch of international literature that studies the possibilities of success solar panel technologies have

\footnotetext{
${ }^{4}$ A massive adoption scenario of the sort presented in this paper could be thought of as a national-scale program. In the last two decades, Mexico has successfully implemented a series of large-scale social programs which have helped create a good reputation in terms of long-term support and commitment. See, for example, Davis et al. (2014), Lobel and Perakis (2011), and Levy (2007).

${ }^{5}$ Unfortunately, we are not able to analyze the impact that the DPVG scenario would have on traditional energy supply. We do not have access to CFE data on production costs that would be necessary to estimate the associated producer surplus changes.
} 
as an alternative clean energy source to traditional power generation -i.e., mainly based on fossil fuels.

In this broader picture, we find mixed evidence to preferences for renewable over conventional energy. Salim and Rafiq (2012) utilizes aggregate data from six major developing countries (Brazil, China, India, Indonesia, Philippines and Turkey) and finds evidence that renewable energy consumption is directly and positively determined by income, and that pollution is inversely associated with renewable energy consumption in three of those six countries. Moving to studies that are grounded on micro data analysis, an early paper by Long (1993) works with several variables that are associated with renewable energy adoption. The author analyzes U.S. data on tax returns, addresses the predictors of energy conservation and renewable energy investments, and finds that energy price changes and subsidies highly influence these expenditures, while the effect of income is not statistically significant. Mills and Schleich (2012) uses household level data from 11 countries in Europe and finds that energy efficient technology adoption and conservation practices are highly correlated with households characteristics. In particular, the presence of young children makes households more likely to care about savings for environmental reasons, while elder households are more likely to care about financial savings. Similarly, Willis et al. (2011) finds evidence that households composed of people aged 65 and over have different behavioral responses to renewable energy adoption: concretely, they are less prone to adopt micro-generation technologies. Furthermore, Bergmann et al. (2008) finds that urban and rural survey respondents have different preferences for renewable energy projects. Scarpa and Willis (2010) uses a household survey for the U.K. to estimate conditional and mixed logit models, and then derives willingness-to-pay for different micro-generation technologies (solar PV, solar thermal, micro-wind, heat pumps, biomass boilers and pellets stoves). This study finds that while renewable energy adoption is significantly valued by residential users, that value is not sufficiently large to most households due to the high initial capital investment. Lastly, Islam and Meade (2013) models the adoption prob- 
ability of PV solar panels by households using rich data from a group of Canadian households on attribute preferences and social characteristics.

In our paper, we are not able to isolate and address the DPV adoption problem. Our dataset only allows us to infer different (arbitrary) DPV technology adoption scenarios, and quantify the potential benefits in terms of household expenditure, electric subsidy reduction, and environmental impact. In order to provide an objective measure of these variables, we choose a particular situation that works as an upper bound of the potential effects. Section 4 below explains in detail our empirical exercise.

In a more specific collect of literature, a number of studies analyze the economic feasibility of DPV systems for residential users. Pillai et al. (2014) proposes a metric to estimate the expected benefits of PV systems in the U.K. and India, and finds that most locations in India would favor from DPV systems usage, whereas most locations in U.K. would need some cost reduction to achieve near-term benefits. The authors also highlight the importance that location-based planning has on policy design. Mitscher and Rüther (2012) studies the competitiveness of grid-connected, DPVG in five Brazilian cities. Assuming a net-metering policy, the authors analyze different scenarios for technology adoption and find evidence that gridconnected PV can be economically competitive in this emerging country.

Finally, there is a complete body of literature analyzing the technical feasibility of massive DPV system adoption with regards to its impact on the electricity network quality, safety and reliability (see for example Caamaño-Martín et al. (2008) and Eftekharnejad et al. (2013) for analysis of the effect on distribution and transmission networks, respectively). In our paper, we leave that discussion aside, and simply assume the current power system is able to accommodate the power generated by the new DPV systems adopted by residential users. ${ }^{6}$

\footnotetext{
${ }^{6}$ Another discussion not contemplated in our paper has to do with unconnected households, typically located in isolated rural areas (see, for example, Bhuiyan et al. (2000) for a case study of remote zones in rural Bangladesh). In the Mexican case, the households connected to the grid are more than $99 \%$ (according to the World Bank, Sustainable Energy for All, Global Electrification Database). Therefore, we only focus on those households connected to the grid.
} 


\section{The context}

\subsection{The Mexican electricity residential sector}

The Mexican residential electricity tariff structure consists of seven tariff classes (namely, 1, $1 \mathrm{~A}, 1 \mathrm{~B}, 1 \mathrm{C}, 1 \mathrm{D}, 1 \mathrm{E}, 1 \mathrm{~F})$ and sixteen regional divisions, linked to average temperatures in a subsidized scheme -i.e. high temperature zones afford lower marginal prices. Some tariff classes have three consumption blocks (i.e., basic, intermediate, and excess) while others have four blocks (i.e., basic, low intermediate, high intermediate, and excess), with some charges changing during summer months. The increasing block tariff structure in each tariff class implies consumption blocks are decreasingly subsidized. Each of the seven tariff classes possesses an annual maximum consumption threshold which, if crossed, makes the corresponding household a high-consumption user (DAC). In that case, the DAC user affords a two-part tariff that is composed of a fixed charge and a marginal price which is substantially more expensive than the regular increasing block price structure mentioned before. Table 1 shows as an example the tariff class 1 in 2016. This tariff class is found across all the sixteen regions but Noroeste and Península.

Table 1: Example of tariff class 1 in 2016

\begin{tabular}{lccc}
\hline $\begin{array}{c}\text { Consumption } \\
\text { Block }\end{array}$ & $\begin{array}{c}\text { Consumption Range } \\
(\mathrm{kWh} / \text { month })\end{array}$ & $\begin{array}{c}\text { Marginal Charge } \\
(\mathrm{MXP})\end{array}$ & $\begin{array}{c}\text { Fixed Charge } \\
(\mathrm{MXP})\end{array}$ \\
\hline Basic & $1-75$ & 0.793 & - \\
Intermediate & $76-140$ & 0.956 & - \\
Excess & $>140$ & 2.859 & - \\
\hline DAC & $>1$ & 3.585 & 92.86 \\
\hline
\end{tabular}

Note: users in class 1 are considered as DAC when annual consumption $>3,000 \mathrm{kWh}$ Source: CFE

Residential users (excluding DAC) received an average subsidy of $60 \%$, whereas households classified as high consumption users pay an end-user price approximately $58 \%$ above 
the marginal cost. DAC users, however, historically represented less than $5 \%$ of total residential consumption. As a result, the government has subsidized almost $60 \%$ of residential electricity consumption during the last decade. Additionally, the number of users connected to the electricity network has also increased and it is expected to keep going up in the coming years. The fiscal burden associated to the residential electricity subsidy increased from 40 billion pesos (MXP) in 1995 (in 2008 constant prices) to 63 billion MXP in 2015, representing approximately $0.5 \%$ of the GDP. Table 2 reports a summary of the sales, costs, subsidies and price-to-cost ratio by tariff class in 2015 . It is evident that the current cross subsidy situation is unsustainable: a reduced number of 'penalized' households classified as DAC users afford a price substantially above production costs but cannot offset the huge deficit caused by the remaining seven under-priced tariff classes.

Table 2: Sales, costs, subsidies and price/cost relationship by tariff class in 2015

\begin{tabular}{lccccc}
\hline $\begin{array}{l}\text { Tariff } \\
\text { Class }\end{array}$ & $\begin{array}{c}\text { Sales } \\
(\mathrm{GWh})\end{array}$ & $\begin{array}{c}\text { Sales } \\
(\text { mill. MXP) }\end{array}$ & $\begin{array}{c}\text { Cost } \\
(\text { mill. MXP) }\end{array}$ & $\begin{array}{c}\text { Subsidy } \\
(\text { mill. MXP) }\end{array}$ & $\begin{array}{c}\text { Price/cost } \\
(\%)\end{array}$ \\
\hline 1 & 20,139 & 22,096 & 59,697 & 37,601 & 37.0 \\
1A & 2,314 & 2,421 & 6,691 & 4,270 & 36.2 \\
1B & 5,807 & 6,255 & 15,061 & 8,806 & 41.5 \\
1C & 12,186 & 14,144 & 28,738 & 14,594 & 49.2 \\
1D & 3,007 & 3,402 & 6,987 & 3,585 & 48.7 \\
1E & 3,861 & 3,791 & 8,761 & 4,970 & 43.3 \\
1F & 6,288 & 5,955 & 13,737 & 7,782 & 43.4 \\
DAC & 2,384 & 8,129 & 5,155 & $-2,974$ & 157.7 \\
\hline Total & 55,986 & 66,193 & 144,827 & 78,634 & 45.7 \\
\hline
\end{tabular}

Source: CFE

As a result, there is an (almost) generalized subsidy scheme which is far from being targeted to the poor. The subsidy explains a heavy and growing fiscal burden to the federal government. Although the main purpose of this study is not to provide a solution to this critical situation, we will provide some potential results (derived from our simulations) that have concrete policy 
implications in terms of the current electric subsidy scheme.

\subsection{Solar panel costs}

According to Fu et al. (2016), the continuing total cost decline of PV modules confirms the economic competitiveness of solar PV for the industry across residential, commercial and utility sectors in the United States. The factors driving the cost reduction are: lower module and inverter prices, optimized system configurations, increased competition, lower installer and developer overheads, and improved labor productivity. Figure 1 shows the long-run evolution of solar PV module prices.

Figure 1: Solar PV module cost (\$/watt)

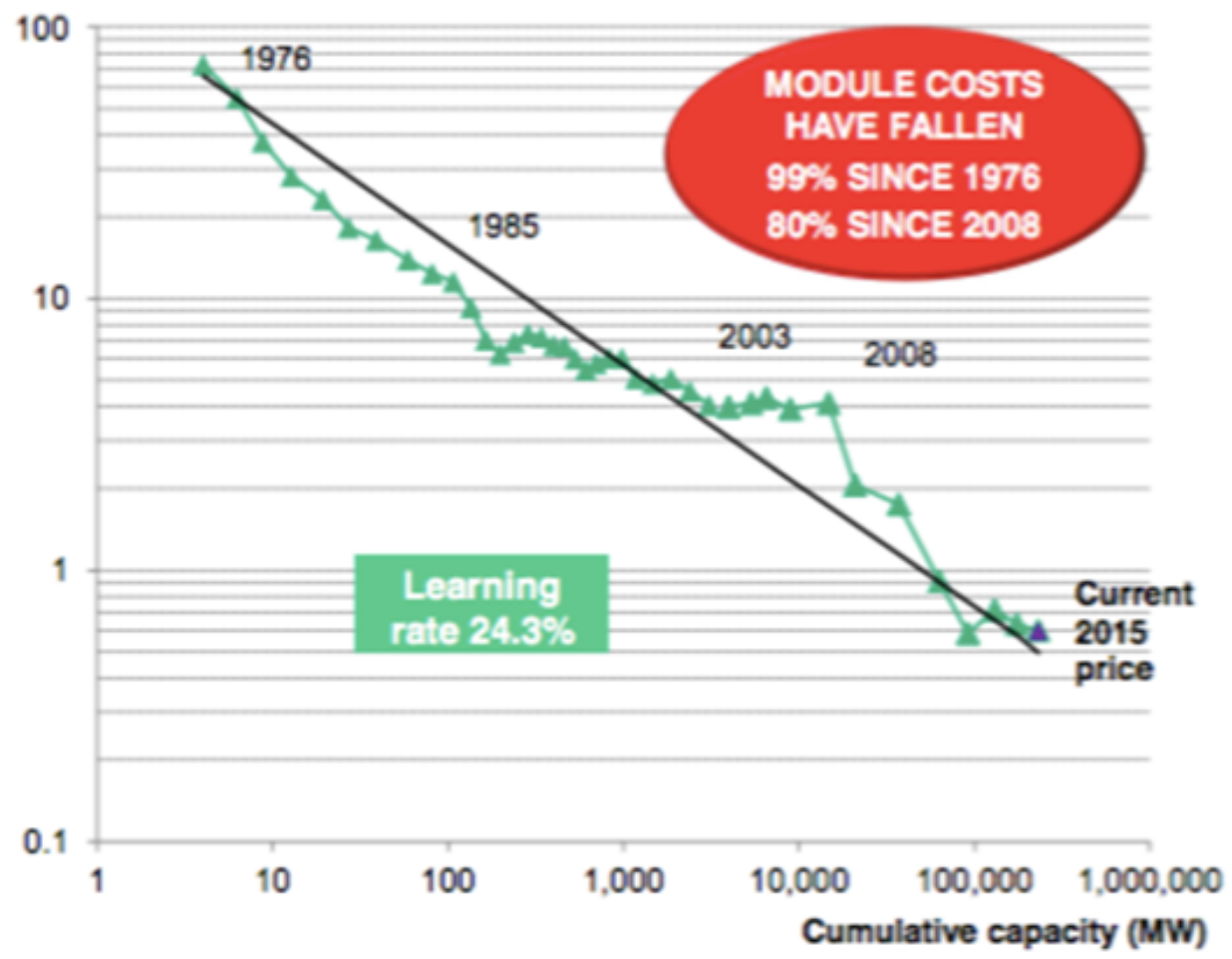

Note: Prices are in real 2015 prices. Source: Bloomberg New Energy Finance, Maycock

In the case of Mexico, the country has similar and even lower hardware costs than U.S., 
and the non-hardware costs (mainly labor during the installation stage) are considerably lower. In the words of leading local PV power developers, ${ }^{7}$ total cost of grid-connected, ready-to-use DPV system is currently below 2 USD per watt of installed capacity. In particular, the 'soft' costs are expected to continue declining as the solar panel industry develops. ${ }^{8}$ In sum, the initial monetary barrier to adopt a PV technology (i.e., the overall adoption cost) is expected to become less significant in the coming years. Therefore, our empirical exercise is a valuable contribution.

\section{Simulation of a national-scale DPVG adoption scenario}

In this section we simulate a massive DPVG program implementation in the Mexican residential sector. Firstly, we use the 2017.1.17 version of the System Advisor Model (SAM) provided by the National Renewable Energy Laboratory (NREL), and simulate the performance of residential PV systems for typical users located in each distribution region and tariff category defined in the previous section. In that context, we consider a representative system that has one single orientation $\left(190^{\circ}\right.$ azimuth and $5^{\circ}$ inclination $), 1: 1 \mathrm{DC}-\mathrm{AC}$ conversion efficiency, $1.6 \%$ inverter efficiency, and $0.5 \%$ performance degradation per year. Table 3 presents the annual generation possibilities that we calculated using the SAM. Following the assumptions in the SAM, we use information of a typical meteorological year and a standard investment cost of 35 Mexican Pesos (MXP) per WDC. The annual operation and maintenance cost is assumed to be $70 \mathrm{MXP}$ per KW of PV capacity installed.

Secondly, we use the 2014 National Household Income and Expenditure Survey (ENIGH2014) collected by the Mexican National Institute of Statistics and Geography (INEGI), the

\footnotetext{
${ }^{7}$ Among which we find Abengoa, Abener, Del Sol Systems, Microm, Iberdrola, Siliken, among several others.

${ }^{8}$ Bollinger and Gillingham (2014) presents a learning-by-doing model and estimates the non-hardware cost reduction in the Californian residential market during the 2002-2012 period. Bazilian et al. (2013) shows a similar pattern for the Brazilian case with sharp price reductions in the market of PV systems.
} 
Table 3: DPV generation assumptions

\begin{tabular}{lcc}
\hline \multicolumn{1}{c}{$\begin{array}{c}\text { CFE } \\
\text { distribution region }\end{array}$} & $\begin{array}{c}\text { Annual average } \\
\text { capacity factor [\%] }\end{array}$ & $\begin{array}{c}\text { Annual DPV generation } \\
\text { for 1 kW DPV [kWh] }\end{array}$ \\
\hline Baja California & $17.5 \%$ & 1533.0 \\
Bajío & $19.4 \%$ & 1699.4 \\
Centro Occidente & $17.9 \%$ & 1568.0 \\
Centro Oriente & $19.1 \%$ & 1673.2 \\
Centro Sur & $18.2 \%$ & 1594.3 \\
Golfo Centro & $17.6 \%$ & 1541.8 \\
Golfo Norte & $17.2 \%$ & 1506.7 \\
Jalisco & $18.8 \%$ & 1646.9 \\
Noroeste & $18.0 \%$ & 1576.8 \\
Norte & $18.9 \%$ & 1655.6 \\
Oriente & $16.0 \%$ & 1401.6 \\
Peninsular & $16.2 \%$ & 1419.1 \\
Sureste & $17.5 \%$ & 1533.0 \\
Valle de Mexico Centro & $18.6 \%$ & 1629.4 \\
Valle de Mexico Norte & $18.0 \%$ & 1576.8 \\
Valle de Mexico Sur & $18.3 \%$ & 1603.1 \\
\hline
\end{tabular}

Source: own calculations based on the SAM provided by NREL. 
CFE tariffs, and the taxes in effect during the sample period ${ }^{9}$ to recover the quantity of electricity consumed by each household. ${ }^{10}$

Thirdly, once we have simulated the performance of a typical DPV system and retrieved electricity consumption for each household included in the ENIGH-2014, we establish some requirements to select the group of households that are able to adopt solar panels in their rooftops. Since our goal is to provide an upper bound of the (potential) program effects, we assume that each household that qualifies as an adopter, does install the corresponding DPVG technology. Concretely, we restrict our attention to dwellings which can support the solar panel structure (e.g., those homes with shingle, concrete slab, or similar roof materials; also solid walls made of bricks, blocks, stone, quarry, cement or concrete; and firm floors made of cement, wood, mosaic, or other coating). We only include independent houses and exclude departments in multi-floor buildings, or commercial premises used as housing. We assume solar panels can only be installed by houses that are occupied by the owners (and exclude rented houses). Given the lack of a variable that indicates the area surface of the house, we take as reference that each room (excluding bathrooms and kitchen) has, on average, 9 square meters of ceiling surface suitable for the adoption of the PV technology. ${ }^{11}$ We also assume that only those households with a generation capacity able to cover the total electricity consumption needs are the ones adopting the solar panels. Finally, to simulate the program impact, we assume connection to the grid is done under a net metering scheme with 2014 end-user electricity tariffs.

The potential (i.e., maximum) number of households that might adopt a DPV system amounts to approximately 15 million households, which practically represents half of the resi-

\footnotetext{
${ }^{9}$ The Value Added Tax (VAT) is 16\%, and some cities also include a Street Lighting Rate which ranges from $5 \%$ to $10 \%$ of the electricity bill.

${ }^{10} \mathrm{We}$ basically invert the corresponding tariff formula from the original household expenditure data. In so doing, we apply a similar methodology to the one used by Navajas (2009) and Hancevic and Navajas (2015).

${ }^{11}$ With regards of the area needed for the rooftop PV panel, we assume $160 \mathrm{~W} / \mathrm{m}^{2}$ with a ground coverage ratio of 0.70 , which leads to approximately $112 \mathrm{~W} / \mathrm{m}^{2}$.
} 
Table 4: Potential DPV system adopters by CFE distribution region

\begin{tabular}{lcc}
\hline \multicolumn{1}{c}{ Distribution region } & \% of adopters & Num. of adopters \\
\hline Bajío & $56.3 \%$ & $1,388,972$ \\
Baja California & $31.0 \%$ & 392,965 \\
Noroeste & $40.6 \%$ & 630,407 \\
Norte & $44.4 \%$ & 727,004 \\
Golfo Norte & $62.6 \%$ & $1,580,272$ \\
Centro Occidente & $47.7 \%$ & 778,566 \\
Centro Sur & $43.8 \%$ & 840,598 \\
Oriente & $34.2 \%$ & 791,027 \\
Sureste & $30.4 \%$ & 846,285 \\
Valle de México Norte & $59.2 \%$ & $1,219,132$ \\
Valle de México Centro & $37.1 \%$ & 574,680 \\
Valle de México Sur & $61.1 \%$ & $1,157,186$ \\
Golfo Centro & $56.4 \%$ & 800,250 \\
Centro Oriente & $58.0 \%$ & $1,271,654$ \\
Peninsular & $58.8 \%$ & 771,601 \\
Jalisco & $55.0 \%$ & $1,247,509$ \\
\hline Total & $48.8 \%$ & $15,018,109$ \\
\hline
\end{tabular}

Source: own calculations using ENIGH 2014. 
dential users as reflected in the ENIGH-2014. ${ }^{12}$ Table 4 illustrates these results discriminating by $\mathrm{CFE}$ distribution regions. The potential PV technology penetration is uneven when looking at the different CFE distribution regions. In this context, Golfo Norte emerges as the region with the largest number of potential adopters.

As mentioned before, we suppose each $\mathrm{KW}$ of installed capacity has a uniform total cost of 35,000 MXP in all regions. The assumed lifespan of each solar panel is 25 years. With those numbers in mind, Table 5 presents the initial outlays for each CFE distribution region. The national average investment cost is approximately 36,000 MXP. The dispersion across regions is, however, considerable. For instance, while the average outlay in the Noroeste region is around 91 thousand MXP, the corresponding number in the Centro Oriente region is only 21 thousand MXP. These significant differences mainly correspond to differences in consumption levels (recall we assume adopters install solar panels to cover their annual electricity consumption).

\subsection{Household Welfare}

Household welfare changes can be divided into two sub-periods: the negative changes in utility or 'losses' derived from the initial investment outlays, and the subsequent utility 'gains' once electric bill savings become effective. Other potential monetary benefits, such as renewable or clean energy certificates (commonly referred to as RECs), are not included in our welfare calculations. The reason is that, by the time this paper was written, RECs were not yet instrumented for residential users in Mexico.

In this section, we measure actual expenditure changes and their corresponding welfare effects. We use a simple methodology to calculate aggregate welfare variations from changes in

\footnotetext{
${ }^{12}$ The actual total number of residential users according to the CFE records in 2016 was approximately 35 million households. The corresponding figure in our study differs since we based our calculations on the ENIGH2014 information. Hence, our study considers a different sample period and relies on the survey sampling weights. We also eliminate several observations due to sensible missing data and/or inconsistencies. In that context, the (expanded) total number of users that we use in this paper is approximately 30 millions.
} 
Table 5: Estimated PV investment cost by distribution region (in MXP)

\begin{tabular}{lcc}
\hline \multicolumn{1}{c}{ Distribution region } & mean & std. dev. \\
\hline Bajío & 24,392 & 9,986 \\
Baja California & 44,276 & 29,026 \\
Noroeste & 91,946 & 46,633 \\
Norte & 41,230 & 21,658 \\
Golfo Norte & 63,570 & 32,869 \\
Centro Occidente & 25,890 & 15,057 \\
Centro Sur & 27,073 & 15,865 \\
Oriente & 33,676 & 21,114 \\
Sureste & 34,629 & 28,116 \\
Valle de México Norte & 23,737 & 13,972 \\
Valle de México Centro & 25,424 & 13,615 \\
Valle de México Sur & 27,472 & 12,677 \\
Golfo Centro & 39,209 & 29,304 \\
Centro Oriente & 21,458 & 10,302 \\
Peninsular & 47,584 & 29,168 \\
Jalisco & 27,811 & 14,848 \\
\hline Total & 36,219 & 28,195 \\
\hline
\end{tabular}

Source: own calculations using ENIGH 2014 and CFE data. 
individual utility assuming a particular social welfare function. Using a simple parameterization (see Newbery $(1995))^{13}$, we assume the social welfare function is additive $W=\sum_{h} U_{h} / H$, where $U_{h}$ is the utility of household $h$ and $H$ is the total number of households. Utility has the following iso-elastic functional form: $U_{h}=x_{h}^{(1-v)} /(1-v)$ when $v \neq 1$, and $U_{h}=\ln \left(x_{h}\right)$ when $v=1$. The variable $x_{h}$ is the household total income (or total expenditure) and the coefficient $v$ can be interpreted as a parameter of social inequality aversion.

Under this specification, the social marginal utility of income (expenditure) is computed by $\beta_{h}=x_{h}^{-v}$, and social welfare can be approximated by the (socially) weighted sum of household income (expenditures). A simple manipulation of the welfare function defined above leads to the following result for the relative welfare change:

$$
\frac{\Delta W}{W}=\frac{\sum_{h} \beta_{h} \Delta x_{h}}{\sum_{h} \beta_{h} x_{h}}
$$

We use this expression later in this study to measure the relative welfare effect of the assumed massive DPV adoption scenario.

\subsubsection{Measurement}

At this stage, we do not consider any specific financing alternative and assume that households pay the initial investment in full during the first period. We also assume a uniform discount rate equal to $2 \%$, which is equivalent to the average real interest rate for time deposit during the last five years in Mexico. Finally, we suppose each household electricity spending grows at a $0.5 \%$ annual rate (measured in real terms).

Table 6 shows the levelized household savings due to DPV system adoption, the project payback period, and the internal rate of return, IRR. There are tariff classes for which adoption

\footnotetext{
${ }^{13}$ Newbery (1995) develops this setting to obtain a workable formula to evaluate distributional impacts of price changes, assuming that real income is unchanged. We change some notation and adapt the model to our measurement purposes.
} 
Table 6: DPV system adoption by tariff category: annualized savings, payback period and internal rate of return

\begin{tabular}{lcclcc}
\hline Tariff class & \multicolumn{2}{l}{ Levelized savings (\$/year) } & \multicolumn{2}{l}{ Payback period (years) } & IRR $(\%)$ \\
\hline 1 & 681.2 & $(993.3)$ & 15.4 & $(4.0)$ & $6.51 \%$ \\
1A & 819.0 & $(1,285.5)$ & 16.0 & $(4.7)$ & $6.62 \%$ \\
1B & 868.9 & $(1,542.4)$ & 17.1 & $(4.8)$ & $5.73 \%$ \\
1C & $1,135.0$ & $(2,202.7)$ & 17.9 & $(4.1)$ & $4.82 \%$ \\
1D & $1,044.0$ & $(2,261.3)$ & 18.5 & $(3.8)$ & $4.00 \%$ \\
1E & 66.7 & $(1,362.1)$ & 23.1 & $(4.0)$ & $1.11 \%$ \\
1F & -441.5 & $(685.9)$ & 24.1 & $(2.4)$ & $0.02 \%$ \\
DAC & $13,616.8$ & $(2,815.7)$ & 5.1 & $(0.5)$ & $26.89 \%$ \\
\hline
\end{tabular}

Source: own elaboration using ENIGH 2014 and CFE. Standard deviations in parenthesis.

is more attractive. Clearly, high consumption users (i.e., DAC) are the most favored ones. On average, each household in this category obtains a reduction of of more than $\$ 13,000$ per year in its expenditure. By contrast, $1 \mathrm{E}$ and $1 \mathrm{~F}$ users have no incentive to adopt the PV technology. The total sum of annualized benefits (net savings) for households adopting a DPV system is approximately 12 billion MXP/year. With regards to the payback period, for a DAC user it only takes 5 years to recover its investment, whereas for an $1 \mathrm{~F}$ user it takes approximately 24 years. The IRR reflects the same pattern: a DAC user can finance the investment with an interest rate of up to $26 \%$. On the other hand, for an $1 \mathrm{~F}$ user the project is unprofitable even with a zero interest rate.

Similarly, Table 7 illustrates the same variables for each CFE distribution region. On average, the adoption of DPV systems seems to be a good investment alternative in most distribution regions. In particular, the Baja California region has the largest expenditure savings and IRR, and the shortest payback period. Conversely, the Noroeste region presents the smallest expenditure savings and IRR, and the longest payback period.

Finally, using equation 1 we provide a measure for the annualized percentage change in household welfare. Tables 8 and 9 present the corresponding estimates assuming an income 
Table 7: DPV system adoption by region: annualized savings, payback period and internal rate of return

\begin{tabular}{|c|c|c|c|c|c|}
\hline \multirow{2}{*}{$\begin{array}{l}\text { CFE distribution region } \\
\text { Bajío }\end{array}$} & \multicolumn{2}{|c|}{ Levelized savings (\$/year) } & \multicolumn{2}{|c|}{ Payback period (years) } & \multirow{2}{*}{$\frac{\operatorname{IRR}(\%)}{6.40 \%}$} \\
\hline & 687.3 & $(953.3)$ & 15.3 & $(3.8)$ & \\
\hline Baja California & $1,867.3$ & $(2,543.3)$ & 13.1 & $(4.6)$ & $8.80 \%$ \\
\hline Noroeste & 178.8 & $(1,729.6)$ & 22.1 & $(4.7)$ & $1.37 \%$ \\
\hline Norte & 970.8 & $(1,575.3)$ & 15.9 & $(4.0)$ & $5.58 \%$ \\
\hline Golfo Norte & $1,005.1$ & $(2,094.6)$ & 18.1 & $(4.8)$ & $4.15 \%$ \\
\hline Centro Occidente & 768.9 & $(1,717.0)$ & 16.1 & $(4.1)$ & $6.67 \%$ \\
\hline Centro Sur & 612.1 & $(1,357.6)$ & 17.3 & $(4.4)$ & $5.41 \%$ \\
\hline Oriente & 912.8 & $(1,874.4)$ & 15.9 & $(4.2)$ & $6.21 \%$ \\
\hline Sureste & 723.7 & $(1,523.6)$ & 17.3 & $(4.4)$ & $5.10 \%$ \\
\hline Valle Mex Norte & 966.2 & $(2,125.9)$ & 14.4 & $(3.6)$ & $8.55 \%$ \\
\hline Valle Mex Centro & 545.1 & $(1,054.1)$ & 17.5 & $(4.3)$ & $5.19 \%$ \\
\hline Valle Mex Sur & 790.2 & $(1,393.9)$ & 16.0 & $(4.5)$ & $6.50 \%$ \\
\hline Golfo Centro & 783.6 & $(1,824.3)$ & 17.3 & $(4.5)$ & $4.93 \%$ \\
\hline Centro Oriente & 637.5 & $(1,174.1)$ & 15.3 & $(3.6)$ & $6.67 \%$ \\
\hline Peninsular & 858.5 & $(1,985.6)$ & 18.6 & $(4.3)$ & $4.57 \%$ \\
\hline Jalisco & 995.8 & $(1,743.5)$ & 14.3 & $(4.0)$ & $7.72 \%$ \\
\hline
\end{tabular}

Source: own elaboration based on ENIGH 2014 and CFE. Standard deviations in parenthesis. 
inequality aversion coefficient $v=2$, which is the most commonly used value in the literature. ${ }^{14}$ The average annual percentage change in household welfare is $5.82 \%$, meaning there is a significant improvement in those households that choose to adopt the PV module. Also, as reflected before, there is considerable dispersion in terms of both tariff classes and regions.

Table 8: Relative change in household welfare by CFE tariff class

\begin{tabular}{lcc}
\hline Tariff class & mean & standard deviation \\
\hline 1 & $5.4 \%$ & $(7.8 \%)$ \\
1A & $7.8 \%$ & $(14.2 \%)$ \\
1B & $6.7 \%$ & $(12.6 \%)$ \\
1C & $6.3 \%$ & $(11.7 \%)$ \\
1D & $6.3 \%$ & $(13.2 \%)$ \\
1E & $-2.7 \%$ & $(13.2 \%)$ \\
1F & $-6.6 \%$ & $(8.9 \%)$ \\
DAC & $44.7 \%$ & $(34.5 \%)$ \\
\hline
\end{tabular}

Source: own elaboration based on ENIGH 2014 and CFE.

As stated before, the DAC users adopting the PV module are the most favored while 1E and $1 \mathrm{~F}$ are clearly in a disadvantaged position. Finally, households located in Baja California (Noroeste) experience, on average, the largest positive (negative) changes in welfare.

\subsection{Opportunity cost pricing}

So far, we have assumed that the current tariff scheme remains unaltered in the future. Accordingly, the current situation where tariffs are heavily subsidized undermines the possibilities of PV system adoption because the savings from not purchasing electricity from the power grid are artificially low. In that sense, without going into the socially optimal design of electricity subsidies, and without suggesting any specific line of reform (which is beyond the scope of this study), Tables 10 and 11 present a simple exercise that serves as benchmark, where users are

\footnotetext{
${ }^{14}$ The basic results do not change significantly if we use alternative values for coefficient $v$. These results are available upon request.
} 
Table 9: Relative change in household welfare by distribution region

\begin{tabular}{lcclcc}
\hline \multicolumn{1}{c}{ Region } & mean & std. dev. & \multicolumn{1}{c}{ Region } & mean & std. dev. \\
\hline Bajío & $5.99 \%$ & $(9.44 \%)$ & Sureste & $5.07 \%$ & $(10.04 \%)$ \\
Baja California & $14.04 \%$ & $(17.93 \%)$ & Valle Méx. Norte & $6.03 \%$ & $(10.53 \%)$ \\
Noroeste & $-1.19 \%$ & $(16.61 \%)$ & Valle Méx. Centro & $3.53 \%$ & $(6.50 \%)$ \\
Norte & $7.72 \%$ & $(12.27 \%)$ & Valle Méx. Sur & $5.00 \%$ & $(7.67 \%)$ \\
Golfo Norte & $4.81 \%$ & $(10.58 \%)$ & Golfo Centro & $5.97 \%$ & $(12.87 \%)$ \\
Centro Occidente & $5.97 \%$ & $(9.90 \%)$ & Centro Oriente & $5.50 \%$ & $(7.65 \%)$ \\
Centro Sur & $5.04 \%$ & $(11.65 \%)$ & Peninsular & $4.55 \%$ & $(9.65 \%)$ \\
Oriente & $6.68 \%$ & $(9.82 \%)$ & Jalisco & $6.76 \%$ & $(9.81 \%)$ \\
\hline
\end{tabular}

Source: own elaboration based on ENIGH 2014 and CFE.

assumed to pay the actual cost of the service. Specifically, we assume a hypothetical situation where electricity prices reflect the long-run sustainable opportunity costs.

Table 10: Annualized savings, payback period and internal rate of return, when opportunity cost pricing is implemented

\begin{tabular}{lccccc}
\hline Tariff class & \multicolumn{2}{c}{ Annualized savings (in \$) } & \multicolumn{2}{c}{ Payback period (in years) } & IRR (in \%) \\
\hline 1 & 765.8 & $(363.2)$ & 11.7 & $(1.1)$ & $10.8 \%$ \\
$1 \mathrm{~A}$ & 859.0 & $(412.3)$ & 11.9 & $(1.3)$ & $10.5 \%$ \\
$1 \mathrm{~B}$ & 881.9 & $(426.4)$ & 12.9 & $(1.6)$ & $9.2 \%$ \\
$1 \mathrm{C}$ & $1,101.5$ & $(523.4)$ & 14.0 & $(1.7)$ & $7.8 \%$ \\
$1 \mathrm{D}$ & $1,238.1$ & $(604.9)$ & 14.4 & $(1.4)$ & $7.8 \%$ \\
$1 \mathrm{E}$ & $1,440.9$ & $(641.8)$ & 14.9 & $(0.5)$ & $8.7 \%$ \\
$1 \mathrm{~F}$ & $1,443.0$ & $(653.8)$ & 16.0 & $(0.2)$ & $8.3 \%$ \\
DAC & $13,616.8$ & $(2,815.7)$ & 5.1 & $(0.5)$ & $26.3 \%$ \\
\hline
\end{tabular}

Source: own elaboration using ENIGH 2014 and CFE. Standard deviations in parenthesis.

If we consider this new staring point, the benefits for households are considerable higher. The larger future electric bill savings entails faster payback periods and higher internal rates of return. Under this hypothetical scenario, even $1 \mathrm{~F}$ users (the least favored group in terms of DPV system possibilities) have a good opportunity to adopt solar panels in their rooftops. Similarly, Table 11 presents the counterfactual outcomes assuming opportunity cost pricing for 
Table 11: Annualized savings, payback period and internal rate of return, when opportunity cost pricing is implemented

\begin{tabular}{lccccc}
\hline \multicolumn{1}{c}{ Region } & \multicolumn{2}{c}{ Annualized savings (in \$) } & \multicolumn{2}{c}{ Payback period (in years) } & IRR (in \%) \\
\hline Bajío & 776.0 & $(509.4)$ & 11.6 & $(0.9)$ & $10.7 \%$ \\
Baja California & $1,553.5$ & $(1,811.9)$ & 10.9 & $(2.4)$ & $10.6 \%$ \\
Noroeste & $1,368.5$ & $(649.9)$ & 15.1 & $(1.5)$ & $8.2 \%$ \\
Norte & $1,051.5$ & $(456.6)$ & 12.5 & $(1.7)$ & $9.3 \%$ \\
Golfo Norte & $1,219.0$ & $(726.3)$ & 14.0 & $(1.9)$ & $8.2 \%$ \\
Centro Occidente & 882.8 & $(1,403.4)$ & 11.8 & $(1.4)$ & $11.1 \%$ \\
Centro Sur & 766.7 & $(899.3)$ & 12.7 & $(1.3)$ & $10.2 \%$ \\
Oriente & $1,006.4$ & $(1,327.9)$ & 12.1 & $(1.5)$ & $10.3 \%$ \\
Sureste & 826.3 & $(466.7)$ & 12.7 & $(1.6)$ & $9.1 \%$ \\
Valle de México Norte & $1,060.1$ & $(1,803.5)$ & 11.4 & $(1.3)$ & $13.1 \%$ \\
Valle de México Centr & 636.1 & $(340.6)$ & 12.6 & $(1.0)$ & $9.4 \%$ \\
Valle de México Sur & 818.0 & $(1,162.4)$ & 12.3 & $(1.3)$ & $9.9 \%$ \\
Golfo Centro & 830.8 & $(440.5)$ & 13.0 & $(1.7)$ & $8.5 \%$ \\
Centro Oriente & 801.0 & $(858.5)$ & 11.6 & $(1.0)$ & $12.1 \%$ \\
Peninsular & 926.9 & $(507.4)$ & 13.9 & $(1.7)$ & $8.2 \%$ \\
Jalisco & $1,019.7$ & $(1,424.4)$ & 11.5 & $(1.4)$ & $11.3 \%$ \\
\hline
\end{tabular}

Source: own elaboration using ENIGH 2014 and CFE. Standard deviations in parenthesis. 
the different CFE distribution regions. On average, all regions receive positive savings when adopting the PV modules.

Table 12: Relative change in household welfare by distribution region when opportunity cost pricing is implemented

\begin{tabular}{lcc}
\hline Tariff class & mean & standard deviation \\
\hline 1 & $10.4 \%$ & $(10.3 \%)$ \\
1A & $13.8 \%$ & $(10.6 \%)$ \\
1B & $13.5 \%$ & $(10.6 \%)$ \\
1C & $14.0 \%$ & $(9.2 \%)$ \\
1D & $19.9 \%$ & $(15.2 \%)$ \\
1E & $28.3 \%$ & $(19.1 \%)$ \\
1F & $28.7 \%$ & $(21.7 \%)$ \\
DAC & $44.1 \%$ & $(34.0 \%)$ \\
\hline
\end{tabular}

Source: own elaboration based on ENIGH 2014 and CFE.

Table 13: Relative change in household welfare by distribution region when opportunity cost pricing is implemented

\begin{tabular}{lcclcc}
\hline \multicolumn{1}{c}{ Region } & mean & std. dev. & \multicolumn{1}{c}{ Region } & mean & std. dev. \\
\hline Bajío & $10,59 \%$ & $(8,04 \%)$ & Sureste & $11,90 \%$ & $(9,71 \%)$ \\
Baja California & $15,96 \%$ & $(12,74 \%)$ & Valle Méx. Norte & $11,06 \%$ & $(11,65 \%)$ \\
Noroeste & $28,55 \%$ & $(21,92 \%)$ & Valle Méx. Centro & $8,21 \%$ & $(5,34 \%)$ \\
Norte & $14,47 \%$ & $(11,06 \%)$ & Valle Méx. Sur & $8,53 \%$ & $(6,78 \%)$ \\
Golfo Norte & $15,87 \%$ & $(11,63 \%)$ & Golfo Centro & $13,84 \%$ & $(10,89 \%)$ \\
Centro Occidente & $12,82 \%$ & $(16,96 \%)$ & Centro Oriente & $11,88 \%$ & $(14,94 \%)$ \\
Centro Sur & $12,92 \%$ & $(10,61 \%)$ & Peninsular & $12,56 \%$ & $(8,78 \%)$ \\
Oriente & $14,23 \%$ & $(11,03 \%)$ & Jalisco & $10,67 \%$ & $(9,87 \%)$ \\
\hline
\end{tabular}

Source: own elaboration based on ENIGH 2014 and CFE.

The relative change in household welfare for each tariff class and distribution region is presented in Tables 12 and 13, respectively. Once again, the results show the larger savings from the higher electricity bills avoided in the future, due to the counterfactual opportunity cost pricing situation. 


\subsection{Government Revenue}

Household electricity consumption is heavily subsidized as pointed out before. On the one hand, the federal government collects the value-added tax (16\% rate), and most local governments collect a street lighting tax (which ranges from 5\% to 10\%) through the electricity bill. The government net revenue results in a significant fiscal deficit. However, if 15 million households described in the previous sections install the DPV system, the government net savings become very significant. For instance, table 14 shows the potential case using information for 2014. Assuming that local governments afford the street lighting costs and that all potential adopters (i.e., 15 million households) install a DPV system to cover $100 \%$ of their annual consumption in a net-metering scheme, the government would save approximately 29 billion MXP annually. The overpayment of DAC users adopting a DPV system represents a loss for the government, but it would be a small fraction of the savings (1,753 MXP in column three of table 14). In the long term, implementing a policy that supports the adoption of DPV systems reduces the needs for a subsidy since the associated variable costs (i.e., operating and maintaining costs of the equipment) are almost negligible. If the lifespan of the PV cells is approximately 25 years, accumulated government savings might amount to more than 500 billions of MXP for the entire period.

The calculations above do not take into account the tax revenues (e.g., income and sale taxes, import tariffs, etc.) that would arise from the booming industry of solar photovoltaic systems if massive adoption occurs. ${ }^{15}$

\subsection{Environmental impacts}

In this section we calculate the environmental impact of the massive DPV system adoption. Our analysis relies on the emission factors recently published by SENER (2017): .00283 kg/kWh

\footnotetext{
${ }^{15}$ In this case, calculations are more complex due to possible tax exemptions to renewable energies and several free trade agreements.
} 
Table 14: Projected government revenue under DVP adoption scenario in 2014 (in Mill. MXP)

\begin{tabular}{lcccc}
\hline Tariff & $\begin{array}{c}\text { Revenue missed } \\
\text { from VAT } \\
(\mathrm{A})\end{array}$ & $\begin{array}{c}\text { Public lighting } \\
\text { spending } \\
(\mathrm{B})\end{array}$ & $\begin{array}{c}\text { Avoided } \\
\text { subsidy } \\
(\mathrm{C})\end{array}$ & $\begin{array}{c}\text { Net } \\
\text { Savings } \\
(\mathrm{C})-(\mathrm{A})-(\mathrm{B})\end{array}$ \\
\hline 1 & $2,172.8$ & 1358.0 & $19,080.7$ & $15,549.9$ \\
1A & 245.5 & 153.4 & $1,736.3$ & $1,337.4$ \\
$1 \mathrm{~B}$ & 422.0 & 263.7 & $3,229.4$ & $2,543.7$ \\
1C & $1,216.8$ & 760.5 & $8,404.3$ & $6,427.0$ \\
1D & 309.4 & 193.3 & $1,883.2$ & $1,380.5$ \\
1E & 236.6 & 147.8 & $2,083.0$ & $1,698.6$ \\
1F & 182.7 & 114.2 & $2,823.4$ & $2,526.5$ \\
DAC & 197.1 & 123.2 & $-1,753.5$ & $-2,073.8$ \\
\hline Total & $4,982.9$ & $3,114.1$ & $37,486.8$ & $29,389.8$ \\
\hline
\end{tabular}

Source: own calculations based on ENIGH 2014 and CFE data.

for $\mathrm{SO}_{2}, .00186 \mathrm{~kg} / \mathrm{kWh}$ for $\mathrm{NO}_{X}, .47753 \mathrm{~kg} / \mathrm{kWh}$ for $\mathrm{CO}_{2}$, and .53836 lts $/ \mathrm{KWh}$ for $\mathrm{H}_{2} \mathrm{O}$. Table 15 presents the environmental outcomes of the massive DPV system adoption scenario -i.e., 15 million households install a DPV system that enables to cover $100 \%$ of household electricity consumption.

As can be seen, the positive environmental effects are very significant, and clearly would help Mexico meet its commitments agreed at COP-21 in Paris, in December 2015, such as the $43 \%$ of the electricity from clean energy sources and the $\mathrm{CO}_{2}$ reduction by 2030 . In the later case, DPVG plan presented here will save about $1 \%$ of the total emissions projected under the INDC mitigation unconditional scenario (Mexico Gobierno de la Republica, 2015). In order to provide a monetary measure, we value emissions and water resource savings. There is no single price for each of these air pollutants and water, and no global agreement has been reached. In the case of Mexico, however, the government sets a tax of around 3 USD per ton of carbon emitted. In some developed countries such as Sweden, the corresponding price could be as high as 130 USD per ton (Ward et al., 2015). According to CONAGUA (2016), the rate per 
Table 15: Projected environmental annual savings under DVP adoption scenario in 2014

\begin{tabular}{lcccc}
\hline Tariff & $\begin{array}{c}\mathrm{SO}_{2} \\
\text { (tons) }\end{array}$ & $\begin{array}{c}\mathrm{NO}_{x} \\
\text { (tons) }\end{array}$ & $\begin{array}{c}\mathrm{CO}_{2} \\
\text { (tons) }\end{array}$ & $\begin{array}{c}\text { Water } \\
(\text { mill. m }\end{array}$ \\
\hline 1 & $27,252.9$ & $17,911.8$ & $4,598,613.9$ & $5,184.4$ \\
$1 \mathrm{~A}$ & $3,056.4$ & $2,008.8$ & $515,732.4$ & 581.4 \\
$1 \mathrm{~B}$ & $5,801.5$ & $3,813.0$ & $978,936.5$ & $1,103.6$ \\
$1 \mathrm{C}$ & $18,083.7$ & $11,885.4$ & $3,051,416.7$ & $3,440.1$ \\
$1 \mathrm{D}$ & $4,952.5$ & $3,255.0$ & $835,677.5$ & 942.1 \\
$1 \mathrm{E}$ & $5,037.4$ & $3,310.8$ & $850,003.4$ & 958.2 \\
$1 \mathrm{~F}$ & $4,329.9$ & $2,845.8$ & $730,620.9$ & 823.6 \\
DAC & 925.4 & 608.2 & $156,152.3$ & 176.0 \\
\hline Total & $69,439.7$ & $45,638.8$ & $11,717,153.6$ & $13,209.4$ \\
\hline
\end{tabular}

Source: own calculations with information from ENIGH and NREL.

cubic meter of water can reach up to 56 MXP for industrial use in Mexico in 2016. Assuming a value of 60 MXP per ton of pollutant and MXP 56 per cubic meter of water, environmental savings would be 1.5 billion of MXP per year.

\section{Capital subsidy, consumption subsidy, or a combination of both?}

The current scheme suffers from the maximum possible inclusion error: it virtually includes all the population of the country. Ideally, in a movement to decrease the heavy electricity subsidy burden, Mexican policymakers should modify the current scheme to better target the subsidy to the poor. However, a deep discussion of this topic clearly has costly political implications, therefore it is not part of the political agenda at the moment. Thus, the simulation in section 4.2 of how a return to opportunity cost pricing would provide correct incentives to DPV system adoption is simply an evaluation exercise, with no possible empirical implementation. 
In this context, an elegant way out of the current massive energy subsidy would be to (partially) replace it for a program that subsidizes the solar panel adoption. Recall from section 4.1.1 that the major obstacle to adoption is the costly initial outlay. This way the new government budget would be practically unaltered during the initial technology adoption phase (e.g., 5 years). However, once a considerable number of households has adopted the PV technology, the overall subsidy account (i.e., electricity subsidy + DPV subsidy) would be substantially reduced (see table 14 for an approximation to the long-run final situation).

From a broader perspective, it is worth emphasizing that a program of the sort described above would eventually imply the replacement of the current consumption subsidy for a capital subsidy. If no action is taken to target the poor, the distributive impact of the new subsidy scheme could be socially undesirable. Table 16 illustrates this point. Using our simulation of section 4, the percentage of potential PV technology adopters reflects an uneven penetration across per capita income deciles. In contrast, with the current electricity subsidy both the percentage of consumption subsidized and the percentage of households receiving the subsidy are more balanced across deciles.

In sum, the current residential electricity subsidy suffers from a critical targeting problem that goes beyond any efficiency consideration: all households, poor and non-poor, are the beneficiaries. And a massive program supporting the adoption of solar panels could end up in a very regressive mechanism. A well-thought-out strategy is needed on how to focus a more complex subsidy structure on the less privileged social classes. It is necessary to bring together a restrictive social tariff scheme that contemplates energy access and consumption ${ }^{16}$, and a program that provides the correct incentives for DPV system adoption. Ideally, both mechanism should rely on a common means testing instrument that properly identifies the qualified households.

\footnotetext{
${ }^{16}$ See, for example, Cont et al. (2008) for a complete analysis of how to implement a social tariff scheme in Argentina.
} 
Table 16: Subsidy beneficiaries by per capita income deciles

\begin{tabular}{cccc}
\hline Decile & $\begin{array}{c}\text { \% of DPV system } \\
\text { adopters }\end{array}$ & $\begin{array}{c}\text { \% of electric bill } \\
\text { subsidized }\end{array}$ & $\begin{array}{c}\% \text { of households } \\
\text { receiving electric subsidy }\end{array}$ \\
\hline 1 & $27.7 \%$ & $66.62 \%$ & $99.03 \%$ \\
2 & $37.5 \%$ & $63.80 \%$ & $99.15 \%$ \\
3 & $40.5 \%$ & $62.27 \%$ & $98.81 \%$ \\
4 & $46.8 \%$ & $62.19 \%$ & $99.15 \%$ \\
5 & $50.3 \%$ & $60.18 \%$ & $98.77 \%$ \\
6 & $54.6 \%$ & $59.80 \%$ & $98.87 \%$ \\
7 & $58.8 \%$ & $58.26 \%$ & $98.54 \%$ \\
8 & $56.6 \%$ & $57.11 \%$ & $98.62 \%$ \\
9 & $58.1 \%$ & $55.29 \%$ & $98.62 \%$ \\
10 & $56.9 \%$ & $50.55 \%$ & $97.55 \%$ \\
\hline Total & $48.8 \%$ & $59.61 \%$ & $98.71 \%$ \\
\hline
\end{tabular}

Source: own calculations based on CFE data and ENIGH 2014.

\section{Concluding remarks and policy implications}

The implementation of a massive DPVG program in the Mexican residential sector would bring more gains than losses. That is true both in economic and environmental terms. Even though residential users are quite heterogeneous, we can identify patterns that are common to most of them. Hence, from the perspective of a representative user (e.g., the average user), the initial investment outlay is more than compensated by the reduction in traditional energy expenditure (i.e., CFE electric bill). ${ }^{17}$ In that context, the current electricity consumption subsidy plays a negative role since for many users it is more attractive to continue paying low energy prices than afford a costly capital investment necessary to install a DPV system. Even for a vast group of households that has an estimated positive net present value from the DPV system adoption, the corresponding payback period could be too long to justify such an investment.

The situation would be quite different if electric prices reflected the actual (true) opportunity costs of generation, transmission, and distribution. In that case net present values and IRR

\footnotetext{
${ }^{17}$ Private benefits could be larger if household utility also worth the social benefits of a cleaner environment.
} 
would be higher, and the payback period would be considerably shorter. However, returning to opportunity cost pricing seems not to be an option under the current political situation. Moreover, a social tariff scheme that correctly target the poor and excludes high-income households from the subsidy is not even discussed. In that context, a partial transformation of the electricity consumption subsidy to a DPV system adoption subsidy could be an alternative.

From the government perspective, each household adopting the PV technology represents a reduction in the subsidy account. This fact opens a real and concrete possibility. It would be possible to implement a mechanism through which the government replaces the current electricity consumption subsidy with a (temporal) DPV system adoption subsidy. In this setting, residential adopters would not suffer from the negative financial effect implied by the costly capital investment during the transition, and the government would simply transfer the resources from one subsidy account to another. In the medium- to long run, all agents involved would benefit from this policy.

Even in the hypothetical subsidy transition scenario described in the previous paragraph, the need for accurate targeting goals emerges once again. If a massive DPV subsidy scheme were to be implemented without a serious livelihood assessment, it could be possible to end up in a undesired situation where the new capital subsidy has a very regressive impact.

From an environmental perspective, the implied outcomes obtained from the massive adoption scenario analyzed in this study are indisputably positive for the whole society. Furthermore, Mexico would be in a better position to comply with the environmental goals agreed in the COP-21 in Paris. However, it is the Mexican government the subject responsible to the environmental goals assumed and not the Mexican households themselves. In this line of thoughts, households adopting a DPV systems should receive the number of RECs that corresponds to the GHG emissions avoided. If this instrument is materialized, the potential benefits of having a DPV system will be larger, and clean technology adoption will be favored.

There are several positive effects (not evaluated in this study), that would materialize in 
the creation of new jobs and investments, especially in the solar panel industry (mainly at the installation stage). Finally, the chances are that the conventional energy producer (i.e., CFE) would become more efficient in a thought strategy to become more competitive.

\section{References}

Gibrán S. Alemán-Nava, Victor H. Casiano-Flores, Diana L. Cárdenas-Chávez, Rocío DíazChavez, Nicolae Scarlat, Jürgen Mahlknecht, Jean-Francois Dallemand, and Roberto Parra. Renewable energy research progress in mexico: A review. Renewable and Sustainable Energy Reviews, 32:140 - 153, 2014.

Morgan Bazilian, Ijeoma Onyeji, Michael Liebreich, Ian MacGill, Jennifer Chase, Jigar Shah, Dolf Gielen, Doug Arent, Doug Landfear, and Shi Zhengrong. Re-considering the economics of photovoltaic power. Renewable Energy, 53:329-338, 2013.

Ariel Bergmann, Sergio Colombo, and Nick Hanley. Rural versus urban preferences for renewable energy developments. Ecological Economics, 65(3):616-625, 2008.

M. M H Bhuiyan, M. Ali Asgar, R. K. Mazumder, and M. Hussain. Economic evaluation of a stand-alone residential photovoltaic power system in Bangladesh. Renewable Energy, 21 (3-4):403-410, 2000.

B. Bollinger and K. Gillingham. Learning-by-doing in solar photovoltaic installation. unpublished manuscript, 2014.

Estefania Caamaño-Martín, Hermann Laukamp, Martin Jantsch, Thomas Erge, Jim Thornycroft, H De Moor, Sjef Cobben, Demet Suna, and Bruno Gaiddon. Interaction between photovoltaic distributed generation and electricity networks. Progress in Photovoltaics: research and applications, 16(7):629-643, 2008. 
CONAGUA. Sistema nacional de tarifas. comisión nacional del aguas, 2016. URL http: //www.conagua.gob.mx/tarifas/.

W. Cont, P. Hancevic, and F. Navajas. Infraestructura y aspectos distributivos en la tarificación de los servicios públicos: ámbito y posibilidades de la tarifa social en la argentina. CAF Working Paper, 2008/03, 2008.

T. Damassa, T. Fransen, B. Haya, M. Ge, K. Pjeczka, and K. Ross. Interpreting indes: Assessing transparency of post-2020 greenhouse gas emissions targets for 8 top-emitting economies. Technical report, WRI Working Paper, 2015.

L. Davis, A. Fuchs, and P. Gertler. Cash for coolers: evaluating a large-scale appliance replacement program in mexico. American Economic Journal: Economic Policy, 6(4):207-238, 2014.

Sara Eftekharnejad, Vijay Vittal, Gerald Thomas Heydt, Brian Keel, and Jeffrey Loehr. Impact of increased penetration of photovoltaic generation on power systems. IEEE Transactions on Power Systems, 28(2):893-901, 2013.

R. Fu, D. Chung, T. Lowder, D. Feldman, K. Ardani, , and R. Margolis. U.s. solar photovoltaic system cost benchmark: Q1 2016. Technical report, National Renewable Energy Laboratory (NREL), 2016.

G. Grande, J. Islas, and M. Rios. Technical and economic analysis of Domestic High Consumption Tariff niche market for photovoltaic systems in the Mexican household sector. Renewable and Sustainable Energy Reviews, 48:738 - 748, 2015.

P. Hancevic and F. Navajas. Consumo residencial de electricidad y eficiencia energética. un enfoque de regresión cuantílica. El Trimestre Económico, 82(328), 2015. 
Towhidul Islam and Nigel Meade. The impact of attribute preferences on adoption timing: The case of photo-voltaic (pv) solar cells for household electricity generation. Energy Policy, 55: 521-530, 2013.

K. Komives, T. Johnson, J. Halpern, J. Aburto, and J. Scott. Residential Electricity Subsidies in Mexico. The World Bank, 2009.

S. Levy. Progress against poverty: sustaining Mexico's Progresa-Oportunidades program. Brookings Institution Press, 2007.

R. Lobel and G. Perakis. Consumer choice model for forecasting demand and designing incentives for solar technology. 2011.

James E. Long. An econometric analysis of residential expenditures on energy conservation and renewable energy sources. Energy Economics, 15(4):232-238, 1993.

L. Lopez-Calva and J. Rosellón. On the potential distributive impact of electricity reform in mexico. 2002.

Mexico Gobierno de la Republica. Intended Nationally Determined Contribution: Mexico. Technical report, Gobierno de Mexico, Mexico, 2015. URL http://www.gob.mx/cms/ uploads/attachment/file/162973/2015\{_\}indc\{_\}ing.pdf.

Bradford Mills and Joachim Schleich. Residential energy-efficient technology adoption, energy conservation, knowledge, and attitudes: An analysis of European countries. Energy Policy, 49:616-628, 2012.

Martin Mitscher and Ricardo Rüther. Economic performance and policies for grid-connected residential solar photovoltaic systems in Brazil. Energy Policy, 49:688-694, 2012.

F. Navajas. Engel curves, household characteristics and low-user tariff schemes in natural gas. Energy Economics, 31(1):162-168, 2009. 
D. Newbery. The distributional impact of price changes in hungary and the united kingdom. The Economic Journal, pages 847-863, 1995.

Gobind G. Pillai, Ghanim A. Putrus, Tatiani Georgitsioti, and Nicola M. Pearsall. Near-term economic benefits from grid-connected residential PV (photovoltaic) systems. Energy, 68, 2014.

Ruhul A. Salim and Shuddhasattwa Rafiq. Why do some emerging economies proactively accelerate the adoption of renewable energy? Energy Economics, 34(4):1051-1057, 2012.

Riccardo Scarpa and Ken Willis. Willingness-to-pay for renewable energy: Primary and discretionary choice of British households' for micro-generation technologies. Energy Economics, 32(1):129-136, 2010.

SENER. Prospectiva del sector eléctrico 2015-2029. Technical report, 2016.

SENER. Primer análisis sobre los beneficios de la generación limpia distribuida y la eficiencia energética en méxico. Technical report, Secretaria de Energia, 2017.

John Ward, Paul Sammon, Guy Dundas, Grzegorz Peszko, Pauline Maree Kennedy, Sebastian Wienges, and Nicolai Prytz. Carbon leakage: theory, evidence, and policy design. partnership for market readiness technical note; no. 11. Technical report, World Bank Group, Washington, D.C., 2015. URL http://documents.worldbank.org/curated/ en/138781468001151104/Carbon-leakage-theory-evidence-and-policy-design.

Ken Willis, Riccardo Scarpa, Rose Gilroy, and Neveen Hamza. Renewable energy adoption in an ageing population: Heterogeneity in preferences for micro-generation technology adoption. Energy Policy, 39(10):6021-6029, 2011. 